TI 2015-079/IV

Tinbergen Institute Discussion Paper

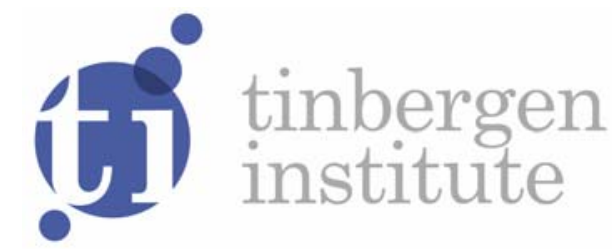

\title{
Mortgage Finance and Technological Change
}

\author{
Robin Döttling \\ Enrico Perotti
}

Faculty of Economics and Business, University of Amsterdam, and Tinbergen Institute, the Netherlands. 
Tinbergen Institute is the graduate school and research institute in economics of Erasmus University Rotterdam, the University of Amsterdam and VU University Amsterdam.

More TI discussion papers can be downloaded at http://www.tinbergen.nl

Tinbergen Institute has two locations:

Tinbergen Institute Amsterdam

Gustav Mahlerplein 117

1082 MS Amsterdam

The Netherlands

Tel.: +31(0)205251600

Tinbergen Institute Rotterdam

Burg. Oudlaan 50

3062 PA Rotterdam

The Netherlands

Tel.: +31(0)10 4088900

Fax: $+31(0) 104089031$

Duisenberg school of finance is a collaboration of the Dutch financial sector and universities, with the ambition to support innovative research and offer top quality academic education in core areas of finance.

DSF research papers can be downloaded at: http://www.dsf.nl/

Duisenberg school of finance

Gustav Mahlerplein 117

1082 MS Amsterdam

The Netherlands

Tel.: +31(0)20 5258579 


\title{
Mortgage Finance and Technological Change
}

\author{
Robin Döttling*1 and Enrico Perotti ${ }^{\dagger 2}$ \\ ${ }^{1}$ University of Amsterdam and Tinbergen Institute \\ ${ }^{2}$ Univesity of Amsterdam, CEPR and Tinbergen Institute
}

June 2015

\begin{abstract}
We explore how house prices evolve under technological progress, when housing serves for consumption as well as store of value. Technological change leads to human capital substituting physical capital and manual labor. Reduced use of physical capital implies that firms have less tangible collateral to pledge for external finance. This results in lower business demand for credit and a decline in interest rates. Over time, savings are redirected to mortgage credit, where houses serve as collateral. Under fixed land supply, house prices rise in real terms. The combination of growing wage inequality and mortgage credit leads to high household leverage for low-skill workers, increasing default rates and foreclosures. Restraining mortgage borrowing is more effective than subsidies to limit mortgage defaults, by containing both leverage and house price appreciation. It also leads to lower interest rates, supporting more corporate investment and higher wages.
\end{abstract}

Keywords. Inequality, mortgage credit, housing, human capital, skill-biased technological change

JEL classifications. D33, E22, E44, R21

\footnotetext{
*Email: $r \cdot j \cdot$ doettling@uva.nl

${ }^{\dagger}$ Email: e.c.perotti@uva.nl

We are very grateful to Bjoern Bruegemann and Eric Bartelsman for their valuable comments. Seminar participant at the University of Amsterdam, the European Central Bank, the VU University Amsterdam and the Tinbergen Institute also provided useful suggestions.
} 


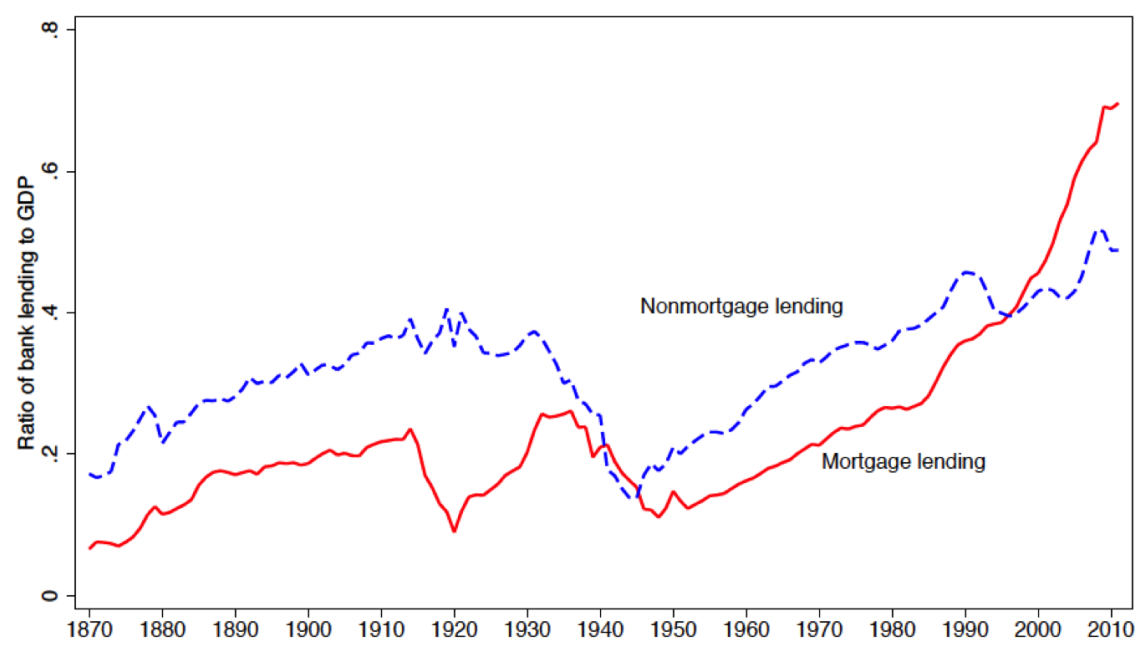

Figure 1: The Great Mortgaging. Source: Jorda et al. (2014)

\section{Introduction}

Real estate credit has grown dramatically in advanced economies, recently surpassing business credit volume (Jorda et al., 2014, see figure 1). This credit expansion, dubbed the Great Mortgaging, funded overwhelmingly house purchases rather than new construction, and was associated with a general (if volatile) increase in house prices. Its scale has raised concerns that the financial system supports asset purchases more than productive activities, while mortgage defaults have proven a key determinant of recent financial instability.

Motivated by this historical development this paper makes two contributions. First, we argue that the growth of mortgage credit may be interpreted in the light of the broad process of technological change towards a knowledge based economy. Information technology has increased the productivity of human capital, enabling it to substitute for physical capital and labor. Our approach studies how technological change shapes the evolution of credit, in the context of a model where overlapping generations purchase housing for consumption as well as for long term saving. We then use the model to evaluate public policies in mortgage markets, such as loan-to-value limits and mortgage subsidies.

Technological change has a direct effect on the relative productivity of factors. The devel- 
opment in information technology since the 1980s has boosted the productivity of high-skill workers while largely substituting low-skill labor, increasing wage inequality (e.g. see Katz and Murphy, 1992; Autor et al., 1998, 2008; Acemoglu and Autor, 2011). At the same time technological change induces firms to use more intangible capital. ${ }^{1}$ Corrado and Hulten (2010a) document how US corporations have been investing more in intangibles over time (see table 1). We highlight here that this has implications for financial intermediation. Intangible capital cannot be easily pledged as collateral to investors, as it depreciates faster and is less appropriable by outsiders. ${ }^{2}$ As a result, less external finance is used to fund production. Recent evidence relates the rising use of intangibles to falling corporate leverage (Bates et al., 2009; Falato et al., 2013). ${ }^{3}$. A falling business credit demand may also explain the steady decline of interest rates since the 1980s.

We introduce technological progress in an overlapping generations setup where housing has both consumption and storage value. Households save to consume in old age, by buying a house when young and reselling it when old, or by investing in financial claims backed by collateral (either physical capital or houses). Buying a house offers some utility value ${ }^{4}$ plus any price appreciation. Mortgage credit enables poorer households to buy a house, competing for net savings with business credit.

Production requires four inputs: physical capital, complementary with manual labor, and intangible capital, complementary with high-skill labor. Physical capital is produced by firms, while intangible capital is produced by some skilled workers who invest their human capital in innovative firms (akin to the innovative producers of intermediate goods in endogenous

\footnotetext{
${ }^{1}$ Falato et al. (2013) define intangibles as knowledge capital, organizational capability and computerized information and software, while Lev (2000) classifies intangibles as innovation-related, human and organizational capital.

${ }^{2}$ While public knowledge is by nature non excludable, the return to worker skills cannot be promised for moral hazard reasons. The only category of intangible capital that may be appropriated are patents and exploitation rights.

${ }^{3}$ The trend is related to a decline in the relative price of certain investment goods, highlighted by Eichengreen (2015) as the key cause of the growing excess of saving over investment.

${ }^{4}$ This inherent consumption value means that houses are not a pure bubble as fiat money in Samuelson (1958)
} 
Table A1.1 Nonfarm Business Fixed Investment rates ${ }^{1}$

\begin{tabular}{|c|c|c|c|c|}
\hline & $\begin{array}{l}1948-2007 \\
\text { (1) }\end{array}$ & $\begin{array}{c}1948-1972 \\
\text { (2) }\end{array}$ & $\begin{array}{c}1973-1994 \\
\text { (3) }\end{array}$ & $\begin{array}{c}1995-2007 \\
\text { (4) }\end{array}$ \\
\hline 1. Tangible & 11.4 & 11.2 & 12.3 & 10.4 \\
\hline 1a. ICT equipment & 1.3 & .6 & 1.6 & 2.0 \\
\hline 1b. Non-ICT equipment & 5.9 & 5.9 & 6.2 & 5.4 \\
\hline 1c. Nonresidential structures ${ }^{2}$ & 3.2 & 3.2 & 3.5 & 2.6 \\
\hline 1d. Residential capital & 1.1 & 1.3 & 1.1 & .8 \\
\hline 2. Intangible & 8.6 & 5.9 & 9.2 & 12.8 \\
\hline 2a. Computerized information ${ }^{3}$ & .6 & .1 & .6 & 1.6 \\
\hline 2b. Innovative property & 3.2 & 1.9 & 3.7 & 4.8 \\
\hline (1) $\mathrm{R} \& \mathrm{D}(\mathrm{NSF} / \mathrm{BEA})$ & 1.4 & .9 & 1.6 & 2.1 \\
\hline (2) Other R\&D, etc. ${ }^{4}$ & 1.2 & .5 & 1.3 & 2.2 \\
\hline (3) Mineral exploration & .6 & .5 & .7 & .5 \\
\hline 2c. Economic competencies & 4.8 & 3.9 & 4.9 & 6.4 \\
\hline (1) Brand equity & 1.6 & 1.6 & 1.5 & 1.8 \\
\hline (2) Firm-specific resources & 3.2 & 2.3 & 3.4 & 4.6 \\
\hline
\end{tabular}

Table 1: Evolution of intangible investment, from Corrado and Hulten (2010a)

growth models (Romer, 1986)).

Technological change alters the relative productivity of factors, leading to rising wage inequality over time. The shift from physical to intangible capital reduces credit demand of traditional firms, while innovative firms engaged in intangible capital accumulation need to be supported by inside equity. As a result a lower fraction of production is financed externally, reducing the supply of savings vehicles. Over time, excess savings over physical investment are redirected to mortgage credit, secured by houses. The combination of lower rates and more credit boost house prices, as land is in fixed supply. ${ }^{5}$

The evolution of house prices and wages induces low-skill workers to take on higher leverage. We show how the combination of the two trends ensures increasing default rates. As foreclosures impose social costs, we study policy options balancing mortgage credit access and financial stability. First, limiting mortgage borrowing, e.g. through loan to value (LTV) limits, has benefits and costs. On the downside, as low skill workers become credit constrained,

\footnotetext{
${ }^{5}$ As housing has direct consumption utility, it maintains its value even with technological progress.
} 
the stock of housing is allocated less efficiently. On the upside, lower leverage reduces default and foreclosures. Additionally, there is a positive general equilibrium effect. Curbing competition for land releases savings that are redirected towards business credit. This reduces the borrowing cost for firms and therefore leads to more physical investment, with a positive effect on wages. Interestingly, the general equilibrium effect tends to benefit most those for whom the borrowing constraint becomes binding, namely young low-skill workers.

Trading off these costs and benefits we show that a limit to mortgage credit can improve steady state welfare. However, this is not a strict Pareto improvement, as the current generation of home owners loses out because houses drop in price. ${ }^{6}$

Mortgage subsidies, commonly practiced in many countries, lead to quite a different result. Since the subsidy is paid by all taxpayers, it is a transfer from rich lenders to poor borrowers. However, as it encourages more mortgage credit it increases house prices and household leverage. The general equilibrium effect is exactly the opposite of an LTV limit, namely a reduction in physical investment and labor wages. Overall, poorer workers may therefore well be worse off despite receiving the subsidy. The difference between the limit and the subsidy is driven by the fact that the supply of land is fixed, so reducing demand is more effective at controlling prices than subsidizing transactions.

The model results need to be qualified by its simplifying assumptions. In the model agents can only consume when they are old, thus the overall supply of savings is not affected by interest rates. $^{7}$ The supply of skill is exogenous, ensuring a steady increase in skill rents. Endogenizing education would dampen the effect on relative wages and inequality, but not the overall trend towards less credit demand by firms. We assume that land supply is fixed, as it is the case for an urban location where housing supply is constrained. Higher prices may lead to more dense housing, but there are countervailing factors such as population growth

\footnotetext{
${ }^{6} \mathrm{~A}$ standard result in the OLG literature is that welfare improvements are only possible in a dynamically inefficient economy. At present, LTV limits are rare, perhaps because current home owners would always resist them.

${ }^{7}$ We take here some comfort from the observed "savings glut" discussed by Bernanke (2005).
} 
and urban zoning limits. ${ }^{8}$ While a more extensive model would incorporate a richer set of effects, our stylized approach enables to combine first order effects of technological change on labor and funding, and their implications on credit allocation, house prices and financial stability.

\subsection{Related literature}

Our approach relates to several established empirical trends. First, the secular rise of mortgage credit and house prices. Second, the increasing use of intangible inputs, and its relation to lower corporate leverage (Falato et al. (2013)). Third, the long term decline in interest rates and the rise in the skill premium.

Turner (Turner, 2014b,a) stresses how at present $75 \%$ of UK bank private credit is extended to households, most as mortgage credit. Also a fair share of business credit funds commercial real estate. Among others, Reinhart and Rogoff (2013) and Schularick and Taylor (2012) document the rise of household leverage. Jorda et al. (2014) connect this to a shift from business towards mortgage lending by documenting The Great Mortgaging depicted in figure 1. Mian and Sufi (2014) explain the Great Recession in terms of the rise in mortgage lending. Mian and Sufi (2009) show how the growth in mortgage credit before the crisis was concentrated among low-income households, and how an increasing supply of local credit drove up house prices. Both results are in line with the model presented in this paper.

The model relies on the notion that pledgeable assets limit external finance, as in Holmstrom and Tirole (1997). ${ }^{9}$ The cross section evidence indicates that external finance requires the pledging of some tangible collateral, and that innovative firms rely more on internal equity (Bates et al., 2009; Falato et al., 2013).

The increasing use of intangible inputs in production is well documented. Corrado and

\footnotetext{
${ }^{8} \mathrm{~A}$ recent survey in the Economist (2015) magazine stressed the explosive increase in urban real estate prices due to strict zoning rules.

${ }^{9}$ As in our model there is no uncertainty over firm value, some external finance may be in the form of equity. A mix of debt and external equity would not alter our result, driven by excess savings relative to tangible investment.
} 
Hulten (2010b) show that in the US the investment rate of intangibles more than doubled from $5.9 \%$ over the period $1948-1972$, up to $12.8 \%$ in $1995-2007$. In contrast, overall investment in physical capital has been rather stable, and the composition of tangible investments has shifted towards IT infrastructure. ${ }^{10}$ The fall of net corporate leverage of US firms (Bates et al., 2009) is associated in the cross section with decreasing capital expenditure and increasing R\&D intensity, as suggested by the model. Falato et al. (2013) find evidence that both net debt and cash are explained by the intangible asset ratio, with a stronger effect for financially constrained firms. In a large sample of COMPUSTAT firms, Giambona et al. (2014) find a significant positive relation between tangibility and leverage in general, and the relation is strongest for real estate collateral. International evidence from Hyytinen and Pajarinen (2005) find lower leverage in Finnish ICT firms than comparable small firms, a difference linked to their R\&D activity, while Hogan and Hutson (2005) find that new technology-based Irish firms rarely use outside debt.

Katz and Murphy (1992) argue that rising demand for educated workers is a driving force on wage structure. Autor et al. (2008) shows both wages and employment in high skill jobs have increased, leading to a higher skill premium. Autor et al. (1998) link this trend to computerization, showing that the rate of skill upgrading has been greater in more computerintensive industries. Similarly, Akerman et al. (2015) show that the adaption of broadband internet increases the labor outcomes of high skill workers but decreases those of low skill workers. For further evidence on the SBTC literature, see Acemoglu and Autor (2011) and Autor (2014).

We adopt the OLG approach developed around Samuelson (1958), Diamond (1965) and Tirole (1985) to describe intertemporal saving behavior. Early overlapping generations models with land include Rhee (1991) and Homburg (1991). These authors are concerned with dynamic inefficiency when land is a factor of production. In contrast, in this paper land is seen as a durable good that can fulfill a storage of value role (as fiat money in Samuelson (1958)), while contributing to agents' utility as a consumption good.

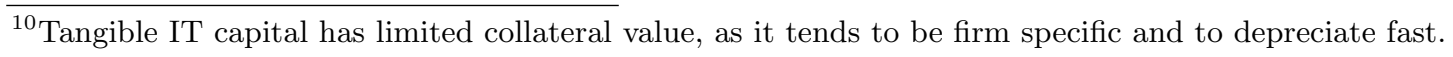


Eichengreen (2015) discusses four key causes of "secular stagnation", defined as the excess of savings over productive technology. Next to falling interest rates he mentions rising net savings in emerging countries and lower population growth, which we do not consider. As most likely cause, Eichengreen (2015) sees the fall in the relative price of certain investment goods, which in Thwaites (2014) explain low interest rates and high house prices. Our general equilibrium approach endogenizes these trends, though in a restated version emphasizing the drop in productivity of tangible capital rather than its cost, which in our model is endogenous.

Our analysis of mortgage defaults complements the political economy narrative of Rajan (2010). In Rajan (2010) the rise of mortgage credit is explained by politicians reacting to increasing inequality, catering low income constituencies. Our dynamic model with endogenous inequality enables to assess policy choices aimed at broadening house ownership, and clearly indicate that restraining leverage is better than subsidizing mortgage credit. The intuition is that because of land fixed supply, subsidizing demand is not efficient, as it only increases price competition and leverage.

The model focuses on interacting economic trends in a context of stationary idiosyncratic risk, and does not aim at explaining systemic crises. However, it implies endogenous trends in compensation and financing that lead wage-earning households to build up increasing mortgage debt. Jordà et al. (2015) find that the growth of mortgage lending has led to property bubbles and financial instability. Property price busts tend to follow credit booms, are long lasting and result in large output losses (for example, see IMF, 2003, 2009; Claessens et al., 2009). The trigger of the recent crisis was default among highly levered, low income households.

The rest of the paper is organized as follows. Section 2 derives the basic model and defines the equilibrium. Section 3 develops our main narrative, connecting technological change to mortgage finance. Section 4 introduces default to the model and analyzes different policy measure. Finally, section 5 concludes. 


\section{The model}

This section describes the baseline model and equilibrium. We start by outlining the model environment.

Time Overlapping generations live for two periods. Generation $t$ is young at time $t$ and old at $t+1$. Time starts at $t=0$ and goes on to infinity. There is an initial generation $t=-1$.

Goods There are two consumption goods, corn and land. ${ }^{11}$ There is a fixed amount of land $\bar{L}$ that is infinitely durable and does not depreciate. The relative price of land in terms of corn at period $t$ is denoted by $p_{t}$.

Agents Each generation consists of a unit mass of households indexed by $i$. Household $i$ of generation $t$ has utility function $U\left(c_{t+1}^{i}, L_{t}^{i}\right)=c_{t+1}^{i}+v\left(L_{t}^{i}\right)$, where $c_{t+1}^{i}$ denotes $i$ 's consumption of corn and $L_{t}^{i}$ its land holdings at the end of period $t$. The function $v(L)$ with $v^{\prime}(L)>0$, $v^{\prime \prime}(L)<0$ captures the utility households achieve from living in their house. A fraction $\phi$ of households is high skill $(i=h)$ and the rest is low-skill $(i=l)$. Each low-skill worker is endowed with $\tilde{l}$ units of manual labor, while a high skill worker has $\tilde{h}$ units of knowledge. Knowledge may be used to operate intangible capital in an existing firm, or be invested in a new firm to generate intangible capital for next period. The initial old generation is endowed with all the land $\bar{L}$.

Innovative entrepreneurs A fraction $\varepsilon$ of high-skill agents has some entrepreneurial talent to create an innovative firm in place of working for an existing firm. Entrepreneurs invest their endowment of skills to create $H_{t+1}^{i}=h_{t}^{i}$ of intangible capital. As entrepreneurs invest only their own human capital, innovative firms have no external financing needs besides inside equity.

\footnotetext{
${ }^{11}$ We do not distinguish between houses and the underlying land and will use the two terms interchangeably.
} 
Representative firm There is an infinitely lived representative firm set up at the initial period with a mandate for value maximization. It has access to a nested CES production technology that takes as inputs physical capital $K_{t}$, manual labor $l_{t}$, intangible capital $H_{t}$ and high-skill labor $h_{t}$ :

$$
Y_{t}=\left[\eta_{t}\left(H_{t}^{\alpha} h_{t}^{1-\alpha}\right)^{\rho}+\left(1-\eta_{t}\right)\left(K_{t}^{\alpha} l_{t}^{1-\alpha}\right)^{\rho}\right]^{\frac{1}{\rho}}
$$

Technological evolution is driven by changes in $\eta_{t}$, associated with the relative productivity of intangible capital. The firm can invest $I_{K, t}$ units of corn at $t$ to create $K_{t+1}=I_{K, t}$ units of capital that can be used in production at $t+1$, producing $K_{t+1}+Y_{t+1}$ units of corn. The firm starts with an initial capital stock $K_{0}$. Intangible capital is acquired each period from the innovative firms, at an unit price equal to $R_{t}$.

Financial contracts Borrowing (or generally external finance) is only feasible if backed by land or by physical capital. ${ }^{12}$ Lending may take place as mortgages backed by land and business loans backed by physical capital. There is no credit risk, so both types of debt earn the same market rate $r_{t}$.

\subsection{Households}

We first consider the behavior of low-skill and high-skill workers without entrepreneurial talent.

Workers Young workers supply their labor endowment inelastically to the representative firm, so worker $i$ has income $y_{t}^{i} \in\left\{w_{t} \tilde{l}, q_{t} \tilde{h}\right\}$ when young, and $y_{t+1}^{i}=0$ when old, where $w_{t}$ denote wages for manual workers and $q_{t}$ wages of high-skill workers. Households only enjoy consumption at $t+1$, so they save all income for retirement. They can buy a house and sell it to the next generation when they are old, earning some utility plus a possible price appreciation. They can also invest in the financial market, lending to firms or to households

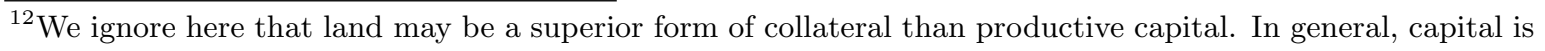
movable while land is not. Moreover, land may be more redeployable.
} 
via mortgages. Let $s_{t}^{i}$ denote net financial savings. We will refer to households with $s_{t}^{i} \geq 0$ as lenders and those with $s_{t}^{i}<0$ as borrowers.

The maximization problem of a household is given in (2), taking prices $p_{t}$ and the market rate $r_{t}$ as given:

$$
\begin{aligned}
\max _{c_{t+1}^{i}, L_{t}^{i}, s_{t}^{i}} U\left(c_{t+1}^{i}, L_{t}^{i}\right) & =c_{t+1}^{i}+v\left(L_{t}^{i}\right) \\
\text { s.t. } \quad s_{t}^{i} & \leq y_{t}^{i}-p_{t} L_{t}^{i} \\
c_{t+1}^{i} & \leq y_{t+1}^{i}+p_{t+1} L_{t}^{i}+\left(1+r_{t+1}\right) s_{t}^{i} \\
s_{t}^{i} & \geq-\bar{m} \\
c_{t+1}^{i}, L_{t}^{i} & \geq 0
\end{aligned}
$$

The first two budget constraints for young and old respectively are binding, else households could increase consumption and thus utility at no cost. The third constraint limits an agent's mortgage borrowing to $\bar{m}$. For now we assume that it is not binding, and that borrowers can fully collateralize the future value of their house, i.e. $\bar{m}=\frac{p_{t+1} L_{t}^{i}}{\left(1+r_{t+1}\right)} \cdot{ }^{13}$ In section 4 we relax this assumption and solve the model with a general $\bar{m}$ at the corner solution where the borrowing constraint is binding.

As the budget constraints are binding, households choose the optimal amount of housing demand by the first order condition

$$
\frac{\left(p_{t+1}-p_{t}\right)+v^{\prime}\left(L_{t}^{i}\right)}{p_{t}}=r_{t+1} .
$$

This has a simple interpretation. Households allocate their savings by weighing the potential price appreciation plus the utility from their house (LHS) against the mortgage interest (RHS, for a borrower), or alternatively, against the opportunity cost of investing in the financial markets (RHS, for a lender). The optimal demand for land follows readily:

$$
L_{t}^{*}=v^{\prime-1}\left(\left(1+r_{t}\right) p_{t}-p_{t+1}\right),
$$

which is independent of the worker's type. Thus, low-skill and high-skill workers have the same demand for housing. ${ }^{14}$ The role of mortgage credit is to allocate land efficiently to

\footnotetext{
${ }^{13}$ This also implies that here the borrowing constraint is equivalent to the non-negativity constraint $c_{t+1}^{i} \geq 0$

${ }^{14}$ This is particular to the case where the borrowing constraint remains slack
} 
equalize across agents the marginal utility from housing. Then financial savings now follow as a residual $s_{t}^{i}=y_{t}^{i}-p_{t} L_{t}^{*}$. Households with $y_{t}^{i} \geq p_{t} L_{t}^{*}$ have an income high enough to buy their house and invest the remainder in the financial market. In contrast, those with $y_{t}^{i}<p_{t} L_{t}^{*}$ take out a mortgage to buy $L_{t}^{*}$. As land has both a consumption and a storage use, mortgage credit serves to separate these two uses: while high income agents need a lot of storage, it would be inefficient if they held a lot of land directly. Instead agents with low incomes sell claims on their houses, providing the necessary storage through the financial market while still enjoying the consumption value of the house.

Entrepreneurs A fraction $\varepsilon$ of high skill agents can start an innovative firm that creates intangible capital, to be sold for productive use the following period. We assume that $\varepsilon$ is small and $\eta$ sufficiently large so that the return to creating intangible capital is always higher than the compensation for skilled labor in existing firms. Then all potential entrepreneurs invest their skill endowment to create intangible capital $H_{t+1}^{i}=\tilde{h}$. They maximize (2) with

$y_{t}^{i}=0$ and $y_{t+1}^{i}=R_{t+1} H_{t+1}^{i}$, where $R_{t+1}$ denotes the return on intangible capital. Since house purchases can be fully collateralized, entrepreneurs can also buy $L_{t}^{i}=L_{t}^{*}$ housing on credit, and save through their human capital invested in their innovative firms. As intangible capital fully depreciates, these firms are dissolved when entrepreneurs retire, and a new cohort produces intangible capital for the next period.

\subsection{The firm's optimization}

Under perfect competition, all factors are compensated according to their marginal products. Intellectual capital supplied by entrepreneurs and manual and high-skill labor supplied by households earn

$$
R_{t}=Y_{H, t}, \quad q_{t}=Y_{h, t}, \quad w_{t}=Y_{l, t}
$$

Since physical capital is fully eligible as collateral, the firm can always finance any tangible investments externally. As long as the return on physical capital exceeds the interest rate 
paid on business loans, the firm scales up tangible investment until:

$$
r_{t}=Y_{K, t} .
$$

Since all factors are compensated according to their marginal product and the production function has constant returns to scale, the representative firm makes zero profits. Consequently, the firm never accumulates internal funds and refinances investment each period, so the business demand for loans is $d_{t}=I_{K, t}$.

To gain intuition for how income is distributed temporarily focus on the special case of a Cobb-Douglas $(\rho \rightarrow 0)$ production function. Then the income share earned by high-skill workers is $(1-\alpha) \eta$, for low-skill workers it is $(1-\alpha)(1-\eta)$. Innovative entrepreneurs earn a share $\alpha \eta$, while the residual $\alpha(1-\eta)$ is earned by creditors of the representative firm who funded the tangible physical capital by $d_{t}=K_{t+1}$. As intangible capital is inherently linked to the human capital of entrepreneurs, it cannot be financed externally, so innovative firms have only internal equity $e_{t}=H_{t+1}$.

This funding structure implies that as intangible capital plays an increasing role in production, overall a smaller fraction of final output is financed externally and less savings are intermediated towards business finance. The excess savings must then be channeled to housing and mortgage finance, the only other savings vehicle.

\subsection{Equilibrium}

Market clearing in the land market requires that $\int_{0}^{1} L_{t}^{i} d i=\bar{L}$, while in the financial market it requires $\int_{0}^{1} s_{t}^{i} d i=d_{t}$. Using (3) leads to the land market equilibrium:

$$
p_{t}=\frac{v^{\prime}(\bar{L})+p_{t+1}}{1+r_{t}}
$$

Using this price in (3) it follows that $L_{t}^{i}=L_{t}^{*}=\bar{L}$ for all $i$. As demand for housing does not depend on wealth, all agents consume the same amount. Similarly we obtain the financial market clearing condition:

$$
(1-\alpha) Y_{t}=p_{t} \bar{L}+K_{t+1}
$$


where the LHS is the savings supply (the total income earned by workers saved for retirement), while the RHS is the total value of land and financial investments. The core of the model is described by (1), (5), (6) and (7).

\section{Technological change}

In this section we study how technological change affects the evolution of housing prices and mortgage finance. In line with the literature, we view technological change as knowledgedriven innovation that disproportionately benefits skilled agents. More precisely, in the model we define technological progress as follows:

Definition 1. Technological progress is the non-stochastic evolution of knowledge $\eta_{t}$ in a parameter range where it increases steady-state output, i.e.

$$
\frac{\partial Y}{\partial \eta}>0
$$

We first derive some comparative statics on $\eta$ in steady state. Then we calibrate the model to match the evolution of intangible-tangible investment ratios from the 1980s to the 2000s, as documented by Corrado et al. (2009) and simulate the transition path generated by the model.

For the sake of tractability, for our analytical results we focus on the Cobb-Douglas case where $\rho \rightarrow 0$ in (1). Additionally, we make one more parameter assumption: ${ }^{15}$

Assumption 1. High-skill labor is relatively scarce:

$$
\frac{\phi(1-\varepsilon)}{(1-\phi)}<\frac{\eta_{t}}{1-\eta_{t}}
$$

This assumption ensures that at any point in time high-skill workers have a higher income than low-skill workers. While highly plausible, it may become less obvious in a setup with endogenous education choice.

\footnotetext{
${ }^{15}$ Earlier we restricted attention to the case where the borrowing constraint in (2) is not binding. We will relax this assumption in the next section.
} 


\subsection{Steady state comparative statics}

We now derive some comparative static results on the effect of technological change $\eta$ on the steady state equilibrium. All proofs are in the apendix. Evaluating (6), the steady state house price level is given by

$$
p=\frac{v^{\prime}(\bar{L})}{r}
$$

The numerator reflects the consumption value of land, which is independent of income and therefore of $\eta$. The denominator reflects its storage value. As higher $\eta$ leads to less demand for business loans, interest rates fall, and the value of housing as storage increases (in other words, it has to be higher to absorb slack savings). Thus, $p$ is decreasing in $r$.

Next, in the Cobb-Douglas formulation wage inequality is given by a simple expression

$$
\frac{q}{w}=\frac{\eta}{1-\eta} \frac{l}{h}
$$

where $l \equiv(1-\phi) \tilde{l}$ and $h=\phi(1-\varepsilon) \tilde{h}$ are the aggregate supply of low and high skill work respectively. Because of its direct effect on the relative productivity of factors in (1) $\eta$ directly increases wage inequality. Based on these two expressions we establish the following intermediate result:

Lemma 1. In steady state technological progress results in falling interest rates, rising house prices and higher wage inequality:

$$
\frac{d r}{d \eta}<0, \quad \frac{d p}{d \eta}>0, \quad \frac{d \frac{q}{w}}{d \eta}>0
$$

Lemma 1 summarizes the two direct effects of technological progress. The first, which is well known in the literature, is that it increases wage inequality. The second and more novel result is that it decreases business credit demand relative to total production, which reduces the supply of savings vehicles and thus interest rates. The channel is that slack savings are absorbed by investment in land. As this is in fixed supply, this results in higher house prices.

With the effect of technological change on house prices and relative factor compensation understood we now show how the two effects combine to influence the volume of mortgage 
credit. As a first step, note that for the financial market to clear mortgage credit cannot be demanded by high-skill workers. Using this result, aggregate mortgage credit $m_{t}$ can be written as follows:

$$
m_{t}=\phi \varepsilon p_{t} \bar{L}+(1-\phi) \max \left\{0, p_{t} \bar{L}-w_{t} \tilde{l}\right\}
$$

The first case in the max-function refers to the case where low-skill workers can still afford their house out of pocket and thus do not take out any mortgage. In the second case both entrepreneurs and low-skill workers take out a mortgage. Evaluating (10) in steady state and dividing by $Y$ it is easy to see that mortgage credit rises relative to GDP whenever $\frac{p}{Y}$ increases, i.e. when house prices rise in real terms. As shown in the following proposition, increasing real house prices coincide with falling absolute wages for low-skill workers and as a result mortgage credit rises.

Proposition 1 (Sufficient condition for rising Mortgage Finance). A necessary and sufficient condition for steady-state house prices to rise relative to $\operatorname{GDP}\left(\frac{d(p / Y)}{d \eta} \geq 0\right)$, and low-skill wages to fall in absolute terms $\left(\frac{d w}{d \eta} \leq 0\right)$, is that technological progress does not result in very strong growth:

$$
\frac{d Y / d \eta}{Y} \leq \frac{1}{1-\eta}
$$

As a result, under this condition steady-state mortgage credit to GDP rises with progress $\left(\frac{d(m / Y)}{d \eta} \geq 0\right)$.

The intuition for this result is as follows. While technological change disproportionately benefits high-skill workers, other factors still benefit to the extent that progress increases overall output. But if growth is not too strong low-skill wages fall in absolute terms. Lower incomes and higher house prices then result in rising leverage.

We have thus established a sufficient condition for technological progress to increase the volume of mortgage credit to GDP. However, as we show in proposition 2 below, $\frac{m}{Y}$ rises under weaker conditions, even when low-skill wages do not decrease. ${ }^{16}$

\footnotetext{
${ }^{16}$ This only applies to the case where low-skill workers buy their house using mortgage credit, i.e. the second case in the max-function in (10). If only entrepreneurs demand mortgages assumption ?? is necessary and
} 
Proposition 2. A necessary and sufficient condition for steady-state mortgage credit to rise relative to $G D P\left(\frac{d(m / Y)}{d \eta} \geq 0\right)$ is that technological progress does not result in extreme growth:

$$
\frac{d Y / d \eta}{Y} \leq \frac{1}{1-\eta}\left[1+\frac{(1-\alpha)^{2} r}{\alpha[(1-\phi)+\phi \varepsilon](p \bar{L} / Y)}\right]
$$

Proposition 2 summarizes our main result that, as long as technological progress does not produce extreme growth, it increases mortgage credit relative to GDP. Note that the condition in proposition 2 is weaker than the condition in proposition 1 . Thus, even when progress increases low-skill wages the volume of mortgage credit rises, as long as wages do not increase too much.

To summarize, technological progress results in output growth, increasing house prices and rising wage inequality. The positive effect on overall output benefits low-skill workers and improves their ability to buy a house with less leverage. But as long as the effect on house prices and relative factor compensation dominates low-skill workers take out larger mortgages, increasing the overall volume of mortgage credit to GDP.

\subsection{Simulated time path of technological change}

We turn now to assess how well this setup explains the evolution of the main endogenous variables by simulating its dynamic version. We calibrate the start and end point of our simulation by assuming that an initial steady state with a low $\eta$ was in place in advanced economies before the IT revolution started in the 1980s, using contemporary measures of the scale of intangible capital. The end point is based on the assumption of a final steady state with a high $\eta$, based on the most recent measures of intangible investment. We then simulate a transition time path from a low- $\eta$ to a high- $\eta$ steady state to dynamically illustrate the results from the comparative statics.

Corrado et al. (2009) measure intangible investment ratios for a growth accounting description for the US economy. The authors offer a series of estimates for the intangible-tangible investment ratio, replicated in table 2 . The relative investment in intangibles appears to have

sufficient for $\frac{m}{Y}$ to rise with technological progress. 


\begin{tabular}{l|c|c|c|c|c|c} 
Period & $1950-59$ & $1960-69$ & $1970-79$ & $1980-89$ & $1990-99$ & $2000-03$ \\
\hline Intangible/tangible ratio & 0.54 & 0.62 & 0.60 & 0.82 & 1.10 & 1.36
\end{tabular}

Table 2: Intangible-tangible investment ratios, annual averages (Corrado et al. (2009))

grown over time from roughly 0.6 before the 1980 s to 1.36 in the early 2000 s. We simulate a transition path from a low- $\eta$ to a high- $\eta$ steady state, calibrated on these ratios and on the relevant US data in the early 1980s. The goal of this exercise is not to make quantitative statements, but to illustrate the qualitative mechanism of the model in a reasonable parameter range. Details on the calibration can be found in appendix D.

The simulated time path is presented in figure 2 . In the simulation $\eta_{t}$ linearly rises over 10 periods, after which the system reaches a new steady state in a few periods. While technological change is associated with GDP growth (upper left panel), it does not benefit all factors equally, so wage inequality rises (upper right panel). In this calibration the condition in proposition 1 holds and low-skill wages actually decrease in absolute terms. Over time investment in physical capital and interest rates decrease (middle left panel), while a lower share of production is funded externally (middle right panel). Finally, house prices rise to absorb slack savings, and leverage for low-skill workers increases. This is reflected in rising mortgage credit as a percentage of GDP, while the share of business credit falls (lower panels).

In conclusion, our model shows how the growth of mortgage credit is driven by increasing income inequality and higher house prices, both independently induced by technological change. In the next section we look at the consequences of increasing household leverage concentrated in a subset of the population, by introducing the possibility of mortgage default. This enables to analyze whether there is a role for public intervention on the mortgage market. 

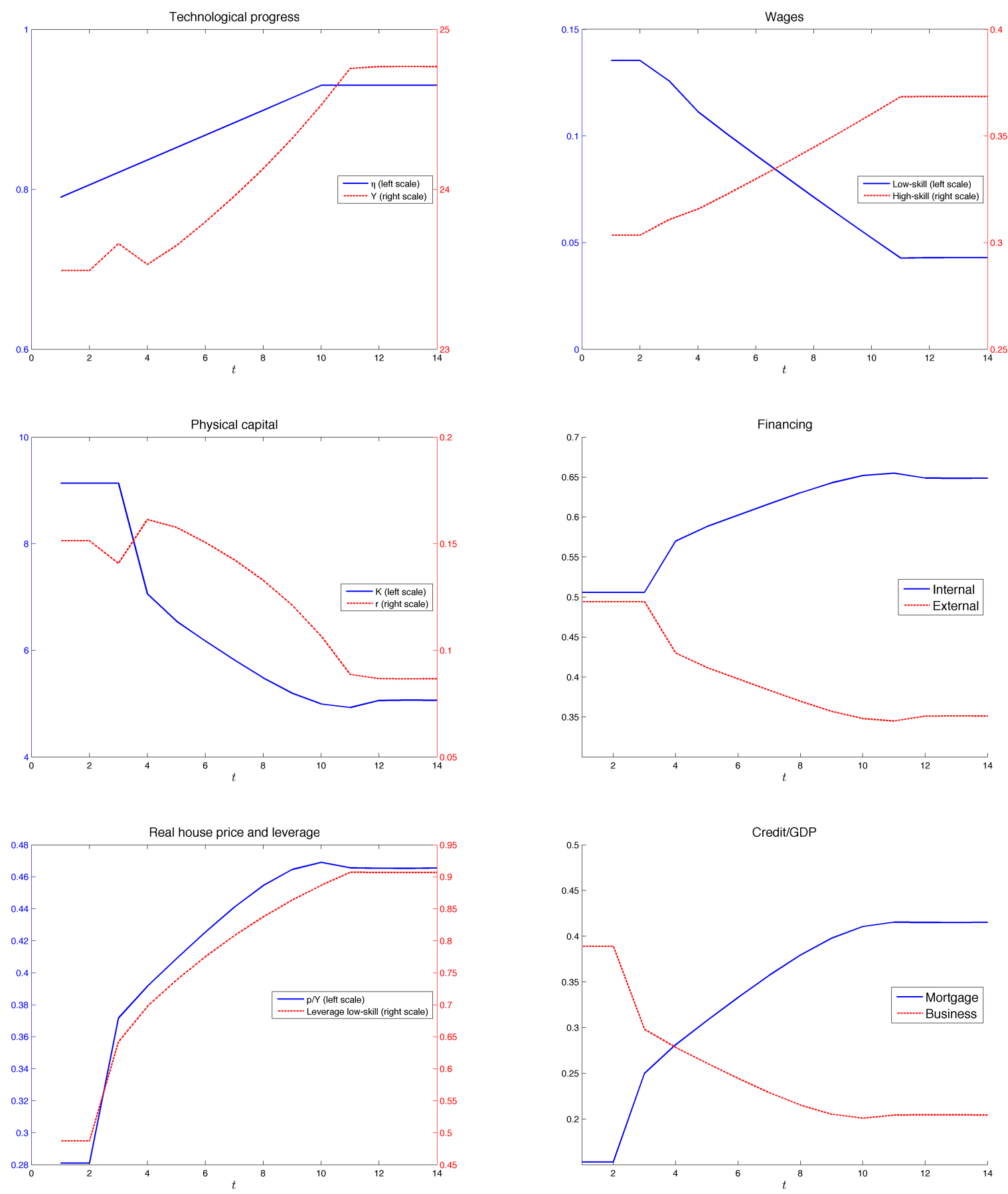

Figure 2: Simulated time path of technological change 


\section{Default and public policy}

The recent crisis was triggered by increasing losses on subprime mortgage credit. Poorer households received abundant credit in the boom to purchase houses, but could not keep up payments on their high debt burden. As a consequence, much policy debate has centered on how to control credit risk in housing and mortgage markets. This section introduces some uncertainty in house prices that may produce default. In the context of our dynamic model, we show how even a stationary distribution of shocks may be compounded by endogenous trends in house prices and income and produce an increasing chance of default.

Default in mortgage markets may justify some policy intervention, as foreclosures arguably have significant negative welfare effects. In addition, public policy on mortgage finance may be justified even in the absence of default, because of its general equilibrium effect on production. Controlling the flow of savings to mortgage credit affects interest rates, boosting credit for productive investments and labor wages. As the economy is dynamically efficient, redirecting savings cannot lead to a Pareto improvement as there would be losers and winners. However, understanding the trade-offs enables to understand why there may be a political majority in favor of a policy with redistributive effects.

The basic policies that may be adopted are either ratio based (loan-to-value (LTV) limits on mortgages) or price based (fiscal subsidies or other financial benefits of mortgage borrowing). We analyze such policies in the context of our model. Interestingly, we find that the most common policy of subsidizing mortgage is counterproductive, while the rarely implemented policy of limiting mortgage leverage is effective at reducing defaults.

\subsection{Default and foreclosure cost}

We now introduce some idiosyncratic risk to allow for the possibility of default. Suppose that after yielding utility to their owner, but before it is sold to the next generation, agent $i$ 's house receives a temporary "bad weather shock" $\xi_{t}^{i}$, with a CDF $G(\xi)$ and zero mean. The weather shock is drawn every period, and its effects are thus temporary. Realizations of $\xi_{t}<0$ mean 
the house stands in a neighborhood that temporarily experiences particularly good weather, yielding their owner some additional utility $-\xi_{t}$ per unit of land in the following period. In contrast, realizations of $\xi_{t}>0$ are bad weather shocks that damage the house. A damaged house will not yield any utility to the next owner unless it is repaired at cost $\xi_{t}$ per unit of land. We focus on the case where the support of $\xi_{t}$ is bounded and small enough that in equilibrium $p_{t}>\xi_{t}$, so repairing the house is always optimal. As the cost has to be ultimately borne by the seller, a damaged house trades at a discount such that $p_{t}^{i}=p_{t}-\xi_{t}^{i}$. This defines a threshold

$$
\hat{\xi}_{t}^{i}=p_{t}+\frac{\left(1+r_{t}\right) s_{t-1}^{i}}{L_{t-1}^{i}}
$$

such that a household defaults on her mortgage if the realization of the shock is $\xi_{t}^{i}>\hat{\xi}_{t}^{i}$. Note that a good weather shock has no effect on the house sale price.

To compensate lenders for the possibility of default, agent $i$ has to pay a risky interest rate. We assume that savers pool their lending through an intermediary that just breaks even, and pays lenders the riskless rate $r_{t}$. Therefore individual lenders always receive $r_{t}$, while borrowers pay it in expectation. The household maximization is analogous to (2). As shown in appendix $\mathrm{E}$, because $\mathbb{E}_{t} \xi_{t+1}^{i}=0$ the problem results in the same first order condition and allocation as (2). However, now households with $\xi_{t}^{i}>\hat{\xi}_{t}^{i}$ default. For concreteness suppose $\xi_{t} \sim U\left[-\frac{\bar{\xi}}{2}, \frac{\bar{\xi}}{2}\right]$. Assuming for simplicity that the return on intangible capital is high enough, low-skill workers are the only borrowers who may default. Aggregate default is then given by

$$
\chi_{t}=(1-\phi) \max \left\{0, \min \left\{\frac{1}{2}-\frac{\hat{\xi}_{t}^{l}}{\bar{\xi}}, 1\right\}\right\} .
$$

A mortgage foreclosure is not just an ex post transfer, but usually imposes some social cost (such as social distress, or some loss of value for the neighborhood). We introduce a nonpecuniary default cost, borne by everybody in society. In particular, suppose foreclosures impose a utility loss $C\left(\chi_{t}\right)$ on every agent, with $C^{\prime}\left(\chi_{t}\right)>0$.

With default and foreclosure costs in the model we have the following corollary to proposition 2: 
Corollary 1. Technological progress that results in rising mortgage credit relative to GDP also produces more default and hence foreclosures in steady state $\left(\frac{d \chi}{d \eta} \geq 0\right)$

As default and foreclosure cost give scope for policy intervention, we examine next the most commonly used quantity and price measures and analyze their welfare consequences.

\subsection{Limiting mortgage borrowing}

Consider first the policy option to limit mortgage credit, such as a limit to loan-to-value (LTV) ratios. Suppose the policy maker limits mortgage borrowing by choosing $\bar{m}$, the maximum allowed size of a mortgage. Limiting mortgage borrowing has benefits and costs. On the downside, whenever $\bar{m}$ is binding, land can no longer be allocated efficiently (that is, uniformly). For simplicity we assume that the borrowing limit is imposed on households, such that entrepreneurs remain unconstrained (e.g. because the policy can be targeted at individuals with low incomes). Further, we make the functional form assumption $v(L)=\ln (L)$ to obtain closed form solutions.

The borrowing constraint becomes binding for low-skill workers when $p_{t} \bar{L}-w_{t} \tilde{l}>\bar{m}$. This forces them to reduce their demand for housing to $L_{t}^{l}=\frac{w_{t} \tilde{t}+\bar{m}}{p_{t}}<\bar{L}$. In equilibrium, educated agents will acquire the rest, $L_{t}^{h}>\bar{L}$. Imposing land market clearing now results in the following land market clearing price evolution, analogous to (6):

$$
p_{t+1}=\left(1+r_{t+1}\right) p_{t}-\frac{\phi p_{t}}{p_{t} \bar{L}-(1-\phi)\left(w_{t} \tilde{l}+\bar{m}\right)}
$$

In a steady state, this results in the expression

$$
p=\frac{\phi+(1-\phi) r(w \tilde{l}+\bar{m})}{r \bar{L}},
$$

which is easily seen to be increasing in $\bar{m}$. Similarly, $L^{l}$ increases in $\bar{m}$ and $L^{h}$ decreases in $\bar{m}$. Thus, for a tighter borrowing limit (lower $\bar{m}$ ) the allocation of land becomes more inefficient, and this is reflected in lower land prices.

When borrowing limits are binding for low-skill workers we have $s_{t}^{l}=-\bar{m}$ and aggregate default (11) can be shown to be increasing in $\bar{m}$. Thus, a tighter borrowing limit reduces default and thus foreclosure cost as expected. 
Interestingly, this policy has also a general equilibrium effect on output. As less savings can be intermediated through house purchases, the released supply of savings leads to more business loans and higher capital investment, ultimately resulting in higher wages. In other words, the policy partially counters the effect of technological change by indirectly subsidizing corporate borrowing and thus encouraging traditional investment in tangible assets.

We now analyze these costs and benefits of limiting mortgage credit in more detail, first in steady state and then dynamically.

\subsubsection{Steady state welfare}

To analyze the costs and benefits of a mortgage limit in the model we use as a welfare function the sum of utilities of all agents, and evaluate it in steady state. Using market clearing conditions this can be written as follows:

$$
\int_{0}^{1} \mathbb{E} U^{i} d i=\int_{0}^{1} v\left(L^{i}\right) d i+p \bar{L}+K+\alpha Y-C(\chi)
$$

Now suppose a planner wanted to set $\bar{m}$ to maximize steady state welfare (12). The first order condition to this problem is given by

$$
\underbrace{\int_{0}^{1} v^{\prime}\left(L^{i}\right) \frac{d L^{i}}{d \bar{m}} d i+\frac{d p}{d \bar{m}} \bar{L}}_{\text {land misallocation }}=\underbrace{-\left[\frac{d K}{d \bar{m}}+\alpha \frac{d Y}{d \bar{m}}\right]}_{\text {output gain }}+\underbrace{C^{\prime}(\chi) \frac{d \chi}{d \bar{m}}}_{\text {less foreclosures }}
$$

The LHS is the cost of tightening the borrowing constraint (lower $\bar{m}$ ), namely a less efficient land allocation. This is reflected in both the utility yield and the land price. Here $\int_{0}^{1} v^{\prime}\left(L^{i}\right) \frac{d L^{i}}{d \bar{m}} d i>0$ and $\frac{d p}{d \bar{m}}>0$, so both the aggregate utility from land and land prices increase in $\bar{m}$ as mortgage credit allows for a more efficient land allocation.

The RHS are the benefits of limiting mortgage credit. The term in square brackets reflects the output gain that comes from the general equilibrium effect described above. As mortgage credit is restricted more savings are intermediated towards production, resulting in higher investment and wages. Here $\frac{d K}{d \bar{m}}<0$ and $\frac{d Y}{d \bar{m}}<0$. The second term is the increasing foreclosure cost as higher leverage results in increasing mortgage default rates. Here $C^{\prime}(\chi)>0$ and $\frac{d \chi}{d \bar{m}}>0$. 
A policy aiming at maximizing steady state welfare will restrict mortgage credit trading off these costs and benefits. Interestingly, low-skill workers tend to benefit most from the LTV ceiling although they are precisely the agents for whom the constraint becomes binding. The reason is that low-skill workers benefit most from the general equilibrium effects of higher investments in physical capital. First, a higher steady state $K$ implies lower interest rates. This is good for low-skill workers because they are borrowers. Second, to the extent that physical capital is more complementary with low-skill than with high-skill labor wages of low-skill workers are boosted disproportionately.

\subsubsection{Dynamic analysis}

So far we have shown that from the perspective of a steady state a policy that limits mortgage borrowing may improve the sum of utilities of all agents. However, a strict welfare improvement is not possible, as this economy is dynamically efficient. ${ }^{17}$ This implies that the moment the borrowing limit is introduced, the old generation of home owners will always lose out as their houses drop in value. Thus, although it is possible to make agents living in steady state better off, dynamically it is impossible to make each and every generation better off.

Our dynamic analysis is illustrated in a simulation where borrowing is gradually limited over 10 periods in figure $3{ }^{18}$ In this simulation we deliberately abstract from foreclosure costs to show that even in the absence of foreclosures limiting borrowing can be beneficial through its general equilibrium effects. The upper left panel plots the demand for mortgage credit by low-skill workers along with the borrowing limit. It can be seen that the constraint actually only becomes binding around period 7, where the two lines meet. Mortgage credit already starts falling before because house prices drop (middle right panel) in anticipation that the constraint will be binding in the future. The upper right and middle left panel illustrate

\footnotetext{
${ }^{17}$ This is a standard result from the OLG literature, see Tirole (1985). An economy may be dynamically inefficient when there is overinvestment, as savings are very abundant and the interest rate is below the rate of population growth. In such a case, introducing a pure asset bubble consumes savings and increases interest rates, reducing excess investment.

${ }^{18}$ The calibration is the same as in the high- $\eta$ steady state in section 3
} 

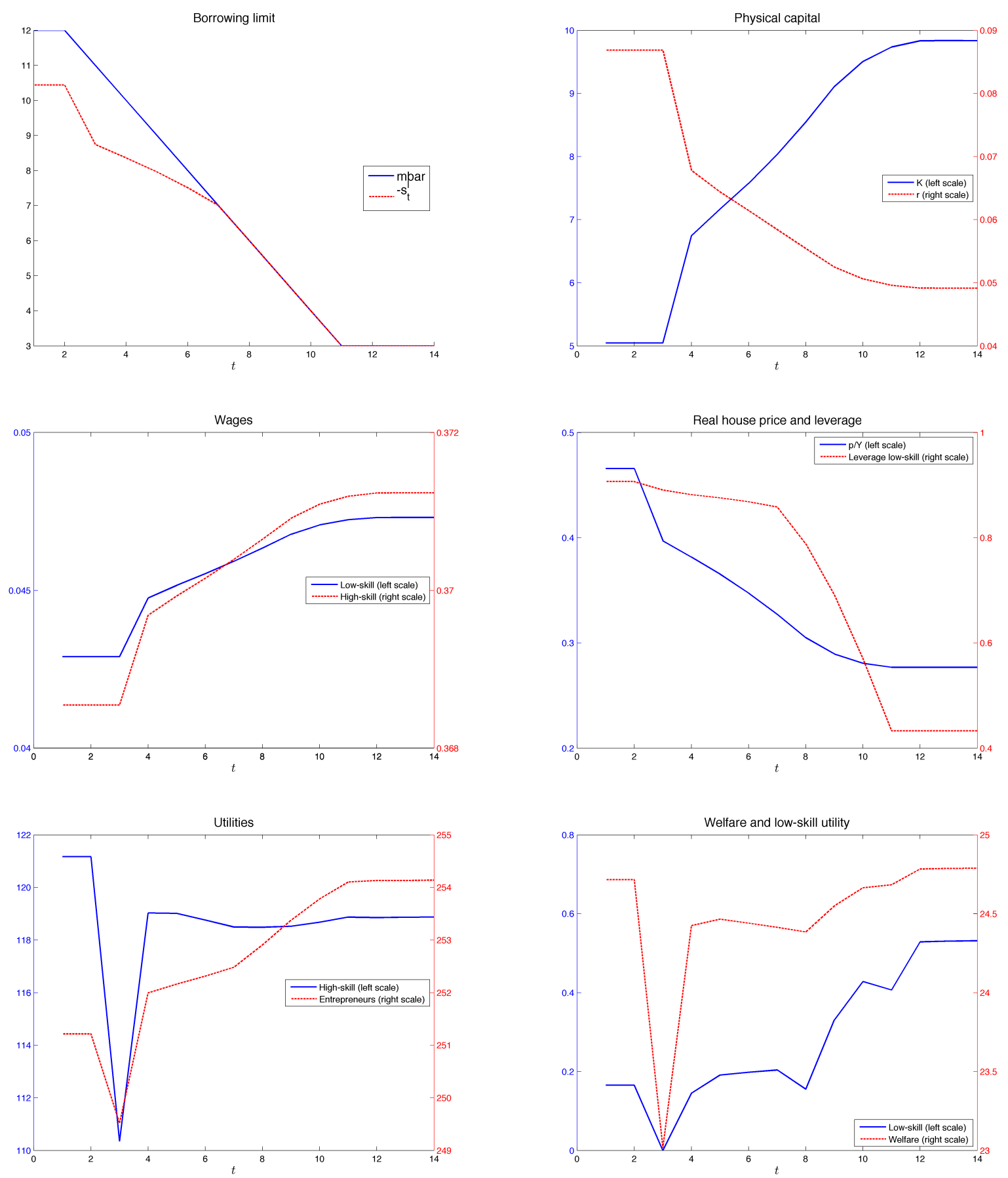

Figure 3: Simulated time path when gradually limiting mortgage credit, without foreclosure costs 
the positive general equilibrium effects of restricting mortgage credit: higher investment and wages, accompanied by a falling interest rate. Wages of low-skill workers increase roughly from 0.043 to 0.047 , or $10 \%$, while those of high-skill workers rise by less than $1 \%$. Finally, the bottom panels display the utilities of entrepreneurs, high-skill and low-skill workers, along with welfare. Here high-skill workers are worse off in the new steady state, while the utilities of entrepreneurs and of low-skill workers, as well as aggregate welfare are higher in the new steady state. The initial dip in the time path shows that the current generation is hit by the introduction of the borrowing ceiling as it results in an unanticipated drop in house prices.

The dynamic perspective on welfare highlights why it may politically actually be quite difficult to introduce limits to mortgage borrowing. The generation of current home owners will always resist such policies, even though in the long run society may be better off. ${ }^{19}$

\subsection{Mortgage subsidies}

Many countries implicitly or explicitly subsidize home mortgages. For example, in the US and in the Netherlands interest payments on mortgages are tax-deductible. The UK government recently introduced the "Help for home buyers" program that grants an interest-free equity loan to home buyers. In the US, government sponsored agencies reduce the lending cost of banks by buying home mortgages. Finally, an OECD study Catte et al. (2004) highlights how in many countries the sale of residential property is exempt from capital gains taxes.

While different in their details, all these policies subsidize property and mortgage financing. We analyze them in a stylized way. Suppose the government pays a subsidy of $\tau_{t}<r_{t}$ on every mortgage, and raises lump-sum taxes $T_{t}$ from the old generation to finance the subsidy. This redistribution favors borrowers while sharing costs with lenders. The subsidy reduces the interest paid on mortgages to $\left(r_{t}-\tau_{t}\right)$. The government budget constraint then requires $-\tau \int_{D}\left(s_{t}(i)\right) d i=T_{t}$, where $D$ is the set of all households that are debtors in the mortgage

\footnotetext{
${ }^{19}$ This result mirrors the analysis of Diamond (1965) who shows that less government debt as an OLG bubble can increase steady state welfare, but that a Pareto-improvement is only possible by increasing government debt when the economy is dynamically inefficient.
} 
market $\left(s_{t}(i)<0\right)$.

For simplicity, suppose the subsidy can be targeted at low-skill workers only, such that rich borrowers (in our model, the entrepreneurs) do not receive the subsidy. Then the aggregate tax burden is $T_{t}=-(1-\phi) \tau_{t} s_{t}^{l}$, and every low skill household receives a subsidy of $-\tau_{t} s_{t}^{l}$. This amounts to a net subsidy of $-\phi^{l} \tau_{t} s_{t}$ per household.

With the subsidy housing demand of low skill workers now is $L_{t}^{p}=v^{\prime-1}\left(\left(1+r_{t}-\tau_{t}\right) p_{t}-p_{t+1}\right)$, while the demand of high skill and rich is the same as before, since they receive no subsidy. Since $L_{t}^{p}$ is increasing in $\tau_{t}$ the subsidy induces low-skill workers to consume more housing. We focus our analysis on how the subsidy changes the steady state allocation. The land price with a subsidy $\tau$ is

$$
p=\frac{r-\phi \tau}{r(r-\tau) \bar{L}},
$$

which is monotonically increasing in $\tau$ for $\tau<r$. For $\tau=0$ the land price is $p=\frac{1}{r L}$, as in the baseline model of section 2. Thus, the subsidy distorts the land price upwards and induces more savings to be intermediated towards housing. Therefore it has exactly the opposite general equilibrium effect of an LTV limit: business credit and investment are discouraged, and wages fall.

Analyzing steady state welfare (12) the mortgage subsidy has two negative effects: first, it results in an inefficient land allocation as low-skill workers demand too much land. Second, there is an output loss because less credit is channeled to production. The effect of the subsidy on default and foreclosures is ambiguous. On the one hand transferring funds to borrowers makes it easier for them to repay their mortgage, so the threshold shock above which low-skill workers default increases to

$$
\hat{\xi}^{l}=p-\frac{(1+r-\tau)\left(-s^{l}\right)}{L^{l}} .
$$

However, through the general equilibrium effects of the subsidy interest rates and house prices increase and wages decrease, so low-skill workers end up with higher leverage. Thus, in sum even defaults may increase and so all three welfare components - land allocation, output and foreclosures - may affect steady state welfare negatively. ${ }^{20}$ These results are illustrated in a

\footnotetext{
${ }^{20} \mathrm{~A}$ strict welfare improvement by reducing mortgage subsidies is again not possible because this economy is
} 

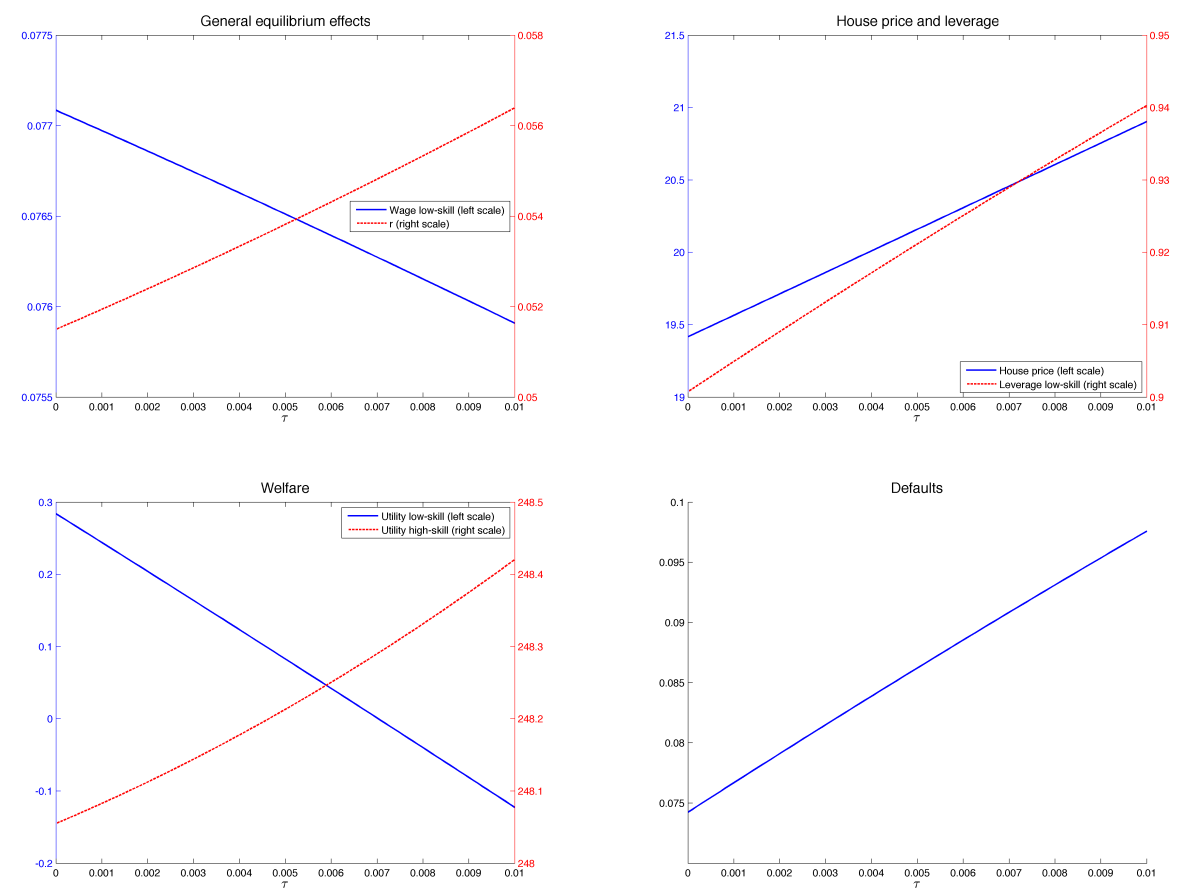

Figure 4: Steady states with different levels of the mortgage subsidy $\tau$.

numerical example in figure 4, where we compare the steady states with different levels of $\tau$. It can be seen in the upper panels that as investment in physical capital goes down, wages decrease and interest rates and house prices increase. In this example the leverage of low-skill workers increases too, resulting in more defaults in equilibrium (bottom right panel). Finally, the lower left panel illustrates the surprising result that due to its general equilibrium effects the receiver of the subsidy (i.e. low-skill workers) may actually be worse off in steady state. In this calibration it is actually high-skill workers who benefit from the subsidy as it results in higher interest rates.

To summarize the policy analysis we compare a mortgage borrowing limit to a subsidy along the three welfare components land allocation, output and foreclosures. First, both policies come with the welfare cost of distorting the land allocation. Second, a mortgage ceiling has positive general equilibrium effects on output, investment and wages, while a subsidy destroys output by diverting savings towards land. Third, a borrowing limit is always effective dynamically efficient, as discussed in the context of the borrowing limit. 
at containing defaults and foreclosures because it reduces leverage. In contrast, because a mortgage subsidy encourages higher leverage it may actually increase default rates despite transferring resources to borrowers.

We conclude that if the purpose of a mortgage subsidy is to support lower income households with buying a house this could more easily be achieved by direct transfers that do not distort the housing market.

\section{Conclusion}

This paper offers a stylized dynamic model where production, factor compensation and financing are driven by technological change, to study its effect on the price and the funding of real estate, a durable asset in fixed supply. Next to established results on the evolution of relative wages, the framework explains concomitant trends in credit allocation and house prices. Our intent is not to offer a complete macroeconomic calibration of the effects of technological progress. We deliberately seek a simple framework to gain some clear insight on the dynamics of mortgage funding and house prices, reconciling several empirical trends. The critical channel is a long term decline in interest rates driven by an increasing use of intangible inputs.

Eichengreen (2015) discusses four factors that may contribute to an excess of saving over productive investment, and lead to a persistent period of below-potential growth (secular stagnation). He examines the rise in saving in emerging markets, the decline in population growth, a drop in investment opportunities, and finally concludes that a fall in the relative price of investment goods (see, e.g. Thwaites, 2014) appears to be the most likely explanation. Our analysis is related to this conclusion. In a world of incomplete contracting, the new technologies boost intangible vs tangible capital, which reduce corporate demand for credit (or more generally, less external financing). Indeed, corporate demand for credit has been falling for years, while net equity issues have been negative. This induces private savings to fund purchases of other durable assets such as housing. Critically, excess savings arise 
because savers cannot co-invest in the private development of intangible capital. In reality, innovative entrepreneurs are largely self financed, in part because they need modest upfront investment. There is much evidence that they receive external finance only at a fairly late stage, once their product is sufficiently tangible. Anecdotal evidence also suggests that value created by innovative firms largely accrues to founders and employees.

Arguably, we still miss a clear framework on the nature of intangible capital and its limited pledgeability. Future research should explore whether this arises from its intellectual nature. Intellectual labor is hard to monitor, so it must be promised large rents to ensure performance. Another issue advanced by the endogenous growth literature is that knowledge, once shared, is non excludable, so it is hard for outsiders to benefit from it. Outside investors then need to rely on tangible assets.

In conclusion, more insight is needed on the evolution of investment funding for an economy driven by technological progress, and specifically knowledge. 


\section{References}

Daron Acemoglu and David Autor. Skills, tasks and technologies: Implications for employment and earnings. Handbook of labor economics, 4:1043-1171, 2011.

Anders Akerman, Ingvil Gaarder, and Magne Mogstad. The skill complementarity of broadband internet. Technical report, National Bureau of Economic Research, 2015.

David H. Autor. Skills, education, and the rise of earnings inequality among the other 99 percent. Science, 344(6186):843-851, 2014. doi: 10.1126/science.1251868.

David H. Autor, Lawrence F. Katz, and Alan B. Krueger. Computing inequality: Have computers changed the labor market? The Quarterly Journal of Economics, 113(4):11691213, 1998. doi: 10.1162/003355398555874.

David H. Autor, Lawrence F. Katz, and Melissa S. Kearney. Trends in U.S. Wage Inequality: Revising the Revisionists. The Review of Economics and Statistics, 90(2):300-323, May 2008.

Thomas W. Bates, Kathleen M. Kahle, and Ren M. Stulz. Why Do U.S. Firms Hold So Much More Cash than They Used To? Journal of Finance, 64(5):1985-2021, October 2009.

Pietro Catte, Nathalie Girouard, Robert Price, and Christophe Andr. The Contribution of Housing Markets to Cyclical Resilience. OECD Economic Studies, 2004(1):125-156, 2004.

Stijn Claessens, M. Ayhan Kose, and Marco E. Terrones. What happens during recessions, crunches and busts? Economic Policy, 24:653-700, October 2009.

Carol Corrado, Charles Hulten, and Daniel Sichel. Intangible capital and u.s. economic growth. Review of Income and Wealth, 55(3):661-685, 2009. ISSN 1475-4991. doi: 10. 1111/j.1475-4991.2009.00343.x.

Carol A. Corrado and Charles R. Hulten. How do you measure a "technological revolution"? American Economic Review, 100(2):99-104, 2010a. doi: 10.1257/aer.100.2.99. 
Carol A Corrado and Charles R Hulten. How do you measure a" technological revolution"? The American Economic Review, pages 99-104, 2010b.

Peter A. Diamond. National debt in a neoclassical growth model. The American Economic Review, 55(5):1126-1150, December 1965.

Barry Eichengreen. Secular Stagnation: The Long View. American Economic Review, 105 (5):66-70, May 2015.

Antonio Falato, Dalida Kadyrzhanova, and Jae W. Sim. Rising intangible capital, shrinking debt capacity, and the US corporate savings glut. Technical report, 2013.

Erasmo Giambona, Joseph Golec, and Armin Schwienbacher. Debt Capacity of Real Estate Collateral. Real Estate Economics, 42(3):578-605, 092014.

Teresa Hogan and Elaine Hutson. Capital structure in new technology-based firms: Evidence from the irish software sector. Global Finance Journal, 15(3):369-387, 2005.

Bengt Holmstrom and Jean Tirole. Financial Intermediation, Loanable Funds, and the Real Sector. The Quarterly Journal of Economics, 112(3):663-91, August 1997.

Stefan Homburg. Interest and Growth in an Economy with Land. Canadian Journal of Economics, 24(2):450-59, May 1991.

Ari Hyytinen and Mika Pajarinen. Financing of technology-intensive small businesses: some evidence on the uniqueness of the ict sector. Information Economics and Policy, 17(1): $115-132,2005$.

IMF. When bubbles burst. World Economic Outlook, Chapter II, pages 61-94, April 2003.

IMF. Lessons for monetary policy from asset price fluctuations. World Economic Outlook, Chapter III, pages 93-120, October 2009. 
Oscar Jorda, Moritz Schularick, and Alan M. Taylor. The great mortgaging: Housing finance, crises, and business cycles. Working Paper 20501, National Bureau of Economic Research, September 2014.

Òscar Jordà, Moritz Schularick, and Alan M Taylor. Betting the house. Journal of International Economics, 2015.

Lawrence F. Katz and Kevin M. Murphy. Changes in relative wages, 1963-1987: Supply and demand factors. The Quarterly Journal of Economics, 107(1):pp. 35-78, 1992. ISSN 00335533

B. Lev. Intangibles: Management, Measurement, and Reporting. Brookings Institution Press, 2000. ISBN 9780815798095.

Atif Mian and Amir Sufi. The Consequences of Mortgage Credit Expansion: Evidence from the U.S. Mortgage Default Crisis. The Quarterly Journal of Economics, 124(4):1449-1496, November 2009.

Atif Mian and Amir Sufi. House of Debt. University of Chicago Press, 2014.

Raghuram G. Rajan. Fault Lines: How Hidden Fractures Still Threaten the World Economy. Princeton University Press, 2010.

Carmen Reinhart and Kenneth Rogoff. Financial and Sovereign Debt Crises: Some Lessons Learned and Those Forgotten. IMF Working Papers 13/266, International Monetary Fund, December 2013.

Changyong Rhee. Dynamic Inefficiency in an Economy with Land. Review of Economic Studies, 58(4):791-97, July 1991.

Paul M Romer. Increasing Returns and Long-run Growth. Journal of Political Economy, 94 (5):1002-37, October 1986.

Paul A. Samuelson. An exact consumption-loan model of interest with or without the social contrivance of money. Journal of Political Economy, 66:467, 1958. 
Moritz Schularick and Alan M. Taylor. Credit Booms Gone Bust: Monetary Policy, Leverage Cycles, and Financial Crises, 1870-2008. American Economic Review, 102(2):1029-61, April 2012.

Gregory Thwaites. Why are real interest rates so low? secular stagnation and the relative price of investment goods. Technical report, 2014.

Jean Tirole. Asset bubbles and overlapping generations. Econometrica, 53(6):1499-1528, November 1985.

Adair Turner. Escaping the debt addiction: Monetary and macro-prudential policy in the post crisis world. Frankfurt lecture, February 2014a.

Adair Turner. Wealth, debt, inequality and low interest rates: Four big trends and some implications. Lecture at Cass Business School, March 2014b. 


\section{A. Proof of proposition 1}

The result on wage inequality is immediate from (9). Further, from (8) it is clear that if $r$ decreases in $\eta$ then $p$ increases.

Thus, all we need to show is that in a steady state under technological progress $\left(\frac{d Y}{d \eta} \geq 0\right)$ interest rates fall in $\eta$, i.e. $\frac{d r}{d \eta} \leq 0$.

The proof uses two equilibrium conditions: the condition that the interest rate equals the marginal product of capital (A.1) and the market clearing condition (A.2), both evaluated in steady state:

$$
\begin{aligned}
r & =\alpha(1-\eta) \frac{Y}{K} \\
(1-\alpha) Y & =\frac{v^{\prime}(\bar{L}) \bar{L}}{r}+K
\end{aligned}
$$

Differentiating (A.1) w.r.t. $\eta$ gives:

$$
\frac{d r}{d \eta}=\alpha \frac{Y}{K}\left[-1+\frac{(1-\eta)}{Y} \frac{d Y}{d \eta}-\frac{(1-\eta)}{K} \frac{d K}{d \eta}\right]
$$

Similarly, rearranging (A.2) for $r$ and taking a derivative w.r.t. $\eta$ yields:

$$
\frac{d r}{d \eta}=\frac{r^{2}}{v^{\prime}(\bar{L}) \bar{L}}\left[\frac{d K}{d \eta}-(1-\alpha) \frac{d Y}{d \eta}\right]
$$

From (A.2') it is easy to see that $\frac{d r}{d \eta} \leq 0$ if

$$
\frac{d K}{d \eta} \leq(1-\alpha) \frac{d Y}{d \eta}
$$

In what follows we show that condition (A.3) indeed holds.

As a first step, setting $\left(\mathrm{A} .1^{\prime}\right)=\left(\mathrm{A} .2^{\prime}\right)$ and solving for $\frac{d K}{d \eta}$ results in

$$
\frac{d K}{d \eta}=\frac{\left[\frac{r(1-\alpha)}{v^{\prime}(\bar{L}) \bar{L}}+\frac{1}{Y}\right] \frac{d Y}{d \eta}-\frac{1}{1-\eta}}{\frac{r}{v^{\prime}(\bar{L}) \bar{L}}+\frac{1}{K}}
$$

Plugging $\frac{d K}{d \eta}$ into (A.3) and rearranging, condition (A.3) can be rewritten as

$$
\frac{d Y}{d \eta}\left[\frac{1}{Y}-\frac{1-\alpha}{K}\right] \leq \frac{1}{1-\eta}
$$


Again using (A.2) this can be rewritten as

$$
-\frac{v^{\prime}(\bar{L}) \bar{L}}{r} \frac{d Y}{d \eta} \leq \frac{1}{1-\eta}
$$

Under technological progress $\frac{d Y}{d \eta} \geq 0$, so the LHS is always negative, while the RHS is always positive. Thus condition (A.3) holds and we can conclude that indeed $\frac{d r}{d \eta} \leq 0$.

\section{B. Proof of proposition 2}

We want to show that in a steady state under technological progress $\frac{d(p / Y)}{d \eta} \geq 0$ and $\frac{d w}{d \eta} \geq 0$ as long as $\frac{1}{1-\eta} \geq \frac{d Y}{d \eta}$.

First, the two for expression $(p / Y)$ and $w$ are given by

$$
\begin{aligned}
\frac{p}{Y} & =\frac{v^{\prime}(\bar{L}) \bar{L}}{r Y} \\
w & =(1-\alpha)(1-\eta) \frac{Y}{l}
\end{aligned}
$$

Regarding wages, taking a derivative w.r.t. $\eta$ it is easily seen that $\frac{d w}{d \eta} \leq 0$ if and only if $\frac{1}{1-\eta} \geq \frac{d Y}{d \eta}$.

From the expression for $\frac{p}{Y}$ one can see that $\frac{d(p / Y)}{d \eta} \geq 0$ if and only if $\frac{d(r Y)}{d \eta} \leq 0$. Combining (A.1) and (A.2) $(r Y)$ can be written as

$$
r Y=\frac{v^{\prime}(\bar{L}) \bar{L}}{(1-\alpha)}+\frac{\alpha(1-\eta)}{(1-\alpha)} Y
$$

Taking a derivative w.r.t. $\eta$ it can be seen that $\frac{d(r Y)}{d \eta} \leq 0$ if and only if $\frac{1}{1-\eta} \geq \frac{d Y}{d \eta}$.

Finally, if $\frac{d(r Y)}{d \eta} \leq 0$ also mortgage credit to GDP is easily seen to increase in $\eta$ :

$$
\frac{m}{Y}=\phi \varepsilon \frac{v^{\prime}(\bar{L}) \bar{L}}{r Y}+\max \left\{0,(1-\phi) \frac{v^{\prime}(\bar{L}) \bar{L}}{r Y}-(1-\alpha)(1-\eta)\right\}
$$




\section{Proof of proposition 3}

In a steady state where low-skill workers take out a mortgage to buy their house, the second case in the max-function in (10) applies and mortgage credit to GDP is given by

$$
\frac{m}{Y}=[(1-\phi)+\phi \varepsilon] \frac{v^{\prime}(\bar{L}) \bar{L}}{r Y}-(1-\alpha)(1-\eta)
$$

Using (B.1) to eliminate $r$ and taking a derivative yields the result that $\frac{d(m / Y)}{d \eta} \geq 0$ if and only if $\frac{d Y / d \eta}{Y} \leq \frac{1}{1-\eta}\left[1+\frac{(1-\alpha)^{2} r}{\alpha[(1-\phi)+\phi \varepsilon](p \bar{L} / Y)}\right]$.

\section{Calibration}

For the calibration we use the functional form $v(L)=\ln (L)$. The parameters of the model are $\alpha, \bar{L}, \phi, \rho, \varepsilon, \tilde{h}$ and $\tilde{l}$. We calibrate all parameters to fit US data from the early 1980s. Then we linearly change $\eta_{t}$ over time, from a starting point $\underline{\eta}$ to an endpoint value $\bar{\eta}$ to match the tangible-intangible investment ratios reported by Corrado et al. (2009). Arguably, to get a more realistic time path one would need to also change other parameters over time. However, since the goal of the simulation is to illustrate the qualitative mechanism of the model we deliberately only change one parameter over time to get a clear picture of the impact of $\eta_{t}$ in the model.

First we normalize $\bar{L}=1$ and set $\alpha=0.33$, a standard value in the literature. For $\phi$ we use the percent of the population with a Bachelor degree or higher in 1980, reported to be $17 \%$ in the Digest of Education Statistics 2013. To calibrate $\rho$ we use the elasticity of substitution between high-skill and low-skill workers. In the SBTC literature this elasticity is measured to be between 1.4 and 2 (Acemoglu and Autor, 2011), so we set $\rho$ to get an elasticity in the center of this range at 1.7 . Finally we set $\varepsilon=0.18$ to match the fraction of self-employed in the US in 1980 of roughly $3 \%$.

This leaves us with two parameters that have no direct representation in the data, namely $\tilde{h}$ and $\tilde{l}$. Additionally, we still need to set the starting- and end values for $\eta_{t}$. To calibrate $\tilde{h}$, $\tilde{l}$ and $\underline{\eta}$ we target the wage gap $\frac{q}{w}$, the level of the interest rate $r$ and the value of intangible- 


\begin{tabular}{|c|c|}
\hline Parameter & Calibration method \\
\hline$\alpha=0.33$ & Income share capital \\
\hline$\phi=0.17$ & Fraction of population with Bachelor degree or higher \\
\hline$\rho=0.7 / 1.7$ & Elasticity of substitution between high-skill and low-skill $=1.7$ \\
\hline$\varepsilon=0.18$ & Target fraction of population self-employed \\
\hline $\bar{L}=1$ & Normalization \\
\hline$\tilde{l}=25, \tilde{h}=305$ & Target steady state interest rate and wage gap \\
\hline$\underline{\eta}=0.79, \bar{\eta}=0.93$ & Target steady state tangible-intangible ratios \\
\hline
\end{tabular}

tangible investment ratios $\frac{R H}{(1+r) K}=0.6$. The wage gap is taken from Autor (2014) who reports a college-high school wage gap of roughly 50\% in 1980. For the interest rate we look at the yield on 10-year US treasury bonds, ranging just below $15 \%$ in 1980, and the intangible-tangible investment ratio is taken from Corrado et al. (2009).

Lastly, with the initial steady state calibrated we choose the endpoint $\bar{\eta}$ to match the Corrado et al. (2009) tangible-intangible investment ratio in the early 2000 s of $\frac{R H}{(1+r) K}=1.36$.

\section{E. Household problem with default}

Denoting the risky rate by $r r_{t}^{i}$ the maximization problem of household $i$ in the model with default becomes

$$
\begin{aligned}
\max _{c_{t+1}^{i}, L_{t}^{i}, s_{t}^{i}} \mathbb{E}_{t} U\left(c_{t+1}^{i}, L_{t}^{i}\right) & =\mathbb{E}_{t} c_{t+1}^{i}+v\left(L_{t}^{i}\right) \\
\text { s.t. } \quad s_{t}^{i} & \leq y_{t}^{i}-p_{t} L_{t}^{i} \\
c_{t+1}^{i} & \leq \max \left\{y_{t+1}^{i}+\left(p_{t+1}-\xi_{t+1}^{i}\right) L_{t}^{i}+\left(1+r r_{t+1}^{i}\right) s_{t}^{i}, 0\right\} \\
s_{t}^{i} & \geq-\bar{m} \\
c_{t+1}^{i}, L_{t}^{i} & \geq 0
\end{aligned}
$$

where the max-function in the $t+1$ budget constraint reflects that households are protected by limited liability. The probability of default is $1-G\left(\hat{\xi}_{t}^{i}\right)$, so that expected consumption at 
$t+1$ can be written as

$$
\mathbb{E}_{t} c_{t+1}=\left(1-\lambda_{t}^{i}\right)\left\{p_{t+1} L_{t}^{i}+\left(1+r r_{t+1}^{i}\right) s_{t}^{i}-\mathbb{E}_{t}\left[\xi_{t+1}^{i} \mid \xi_{t+1}^{i} \leq \hat{\xi}_{t+1}^{i}\right]\right\}
$$

Now, the break even condition for the intermediary on borrower $i$ is

$$
-\left(1+r_{t+1}\right) s_{t}^{i}=-G\left(\hat{\xi}_{t}^{i}\right)\left(1+r r_{t}^{i}\right) s_{t}^{i}+\left(1-G\left(\hat{\xi}_{t}^{i}\right)\right)\left(p_{t+1}-\mathbb{E}_{t}\left[\xi_{t+1}^{i} \mid \xi_{t+1}^{i}>\hat{\xi}_{t+1}^{i}\right]\right) .
$$

Plugging this condition into $\mathbb{E}_{t} c_{t+1}$ the objective function can be written as follows

$$
\mathbb{E}_{t} U\left(c_{t+1}^{i}, L_{t}^{i}\right)=y_{t+1}^{i}+p_{t+1} L_{t}^{i}+\left(1+r_{t+1}\right)\left(y_{t}^{i}-p_{t} L_{t}^{i}\right)+v\left(L_{t}^{i}\right)
$$

The household problem boils down to choosing $L_{t}^{i}$ to maximize $\mathbb{E}_{t} U\left(c_{t+1}^{i}, L_{t}^{i}\right)$. Differentiating w.r.t $L_{t}^{i}$ results in the first order condition and thus demand for land (3). It follows that the allocation in the model with default is equivalent to the model without default. 